DOI: $10.19195 / 0137-1134.114 .12$

\author{
ANNA PISZCZ \\ Uniwersytet w Białymstoku \\ piszcz@uwb.edu.pl
}

\title{
STOSOWANIE PRAWA \\ A KONTROLA JEGO KONSTYTUCYJNOŚCI (ZDANIA ODRĘBNE PROFESORA LEONA KIERESA DO WYROKÓW TRYBUNAŁU KONSTYTUCYJNEGO)
}

\begin{abstract}
Abstrakt: W niniejszym artykule czytelnik znajdzie informacje o zdaniach odrębnych Prof. Leona Kieresa do wyroków Trybunału Konstytucyjnego. Intencją autorki jest przedstawienie poglądów Profesora na stosowanie prawa w różnych kontekstach. Stąd też kolejne części artykułu prezentują przegląd jego poglądów w następujących kwestiach: stosowanie prawa a zdolność skargowa, wadliwe stosowanie prawa/nieznajomość prawa a ocena konstytucyjności, stosowanie niekonstytucyjnego aktu a konieczność kontroli, przyszła praktyka stosowania prawa a jego konstytucyjność.
\end{abstract}

Słowa kluczowe: stosowanie prawa, kontrola konstytucyjności, wyroki Trybunału Konstytucyjnego, zdania odrębne

\section{WPROWADZENIE}

Profesor dr hab. Leon Kieres to niekwestionowany autorytet w nauce polskiego prawa administracyjnego i gospodarczego. Od wielu lat jest również wybitną postacią polskiego życia publicznego. Jubilatowi powierzano wiele zaszczytnych funkcji i ról. Pełniąc owe funkcje publiczne, mógł w pełni korzystać z ogromnej wiedzy, którą posiadł. Dotyczy to również służby sędziego Trybunału Konstytucyjnego, którym Leon Kieres został 23 lipca 2012 roku. Od tego czasu brał udział w rozpoznawaniu licznych spraw toczących się przed Trybunałem Konstytucyjnym i orzekaniu w tych sprawach, także w roli przewodniczącego czy sprawozdawcy.

Orzeczenia Trybunału Konstytucyjnego są ostateczne, podlegają jednak ocenie społecznej, w szczególności w środowiskach akademickich ${ }^{1}$. Stanowisko doktryny

1 Por. R. Piotrowski, Konstytucja i uniwersytety, [w:] Prawo, parlament i egzekutywa we wspótczesnych systemach rządów. Księga poświęcona pamięci Profesora Jerzego Stembrowicza, red. S. Bożyk, Białystok 2009, s. 155. 
może mieć wpływ na zmianę kierunku orzecznictwa, zwłaszcza gdy zróżnicowanie poglądów sędziów Trybunału Konstytucyjnego znajdzie wyraz w korzystaniu przez nich z możliwości zgłoszenia zdania odrębnego ${ }^{2}$. To ostatnie uprawnienie wynika obecnie z art. 106 ust. 3 ustawy z 30 listopada 2016 roku o organizacji i trybie postępowania przed Trybunałem Konstytucyjnym ${ }^{3}$. Przepis ów umożliwia członkowi składu orzekającego, który nie zgadza się z większością głosujących, zgłoszenie przed ogłoszeniem orzeczenia zdania odrębnego z uzasadnieniem w formie pisemnej, co zaznacza się w orzeczeniu; zdanie odrębne może dotyczyć także samego uzasadnienia orzeczenia. W praktyce zdarza się też, że votum separatum polega na poparciu w całości bądź w części zdania odrębnego innego sędziego.

Sędzia Trybunału Konstytucyjnego ma prawo nie zgodzić się ze zdaniem większości i ujawnić swe odmienne stanowisko w sprawie. Znacznie większą rolę niż w prawie kontynentalnym odgrywają vota separata w prawie anglosaskim, ze względu na specyfikę prawa precedensowego ${ }^{4}$. Nawet jednak w prawie kontynentalnym zdania odrębne sędziów mogą wywierać wpływ na przyszłe orzeczenia, istotnie zmieniając albo choćby nieznacznie korygując linię orzeczniczą w późniejszych rozstrzygnięciach (jakkolwiek w polskich naukach prawnych problematyka ta nie doczekała się kompleksowych opracowań ${ }^{5}$ ).

Leon Kieres, wykonując obowiązki sędziego Trybunału Konstytucyjnego, korzystał z uprawnienia do zgłoszenia zdania odrębnego. Niniejszy krótki tekst przygotowany w hołdzie Jubilatowi jest inspirowany właśnie zdaniami odrębnymi Jubilata do wyroków Trybunału Konstytucyjnego. Do jego przygotowania wybrano pięć wyroków Trybunału z lat 2013-2017. W zdaniach odrębnych do wybranych wyroków Prof. Kieres zgłaszał cenne uwagi dotyczące między innymi stosowania prawa w kontekście kontroli jego konstytucyjności, które zostaną przedstawione dalej.

\section{STOSOWANIE PRAWA A ZDOLNOŚĆ SKARGOWA}

Na podstawie art. 79 Konstytucji RP z 2 kwietnia 1997 roku $^{6}$ każdy, którego konstytucyjne wolności lub prawa zostały naruszone, ma prawo, na zasadach określonych w ustawie, wnieść skargę do Trybunału Konstytucyjnego w sprawie zgodności z Konstytucją ustawy lub innego aktu normatywnego i na tej podstawie

2 Zob. B. Zdziennicki, Zdania odrębne w orzecznictwie polskiego Trybunatu Konstytucyjnego, [w:] Ksiegga XX-lecia orzecznictwa Trybunatu Konstytucyjnego, red. M. Zubik, Warszawa 2006, s. $135 \mathrm{n}$.

3 Dz.U. z 2016 r. poz. 2072.

4 Tak T. Zych, W poszukiwaniu pewności prawa. Precedens a przewidywalność orzeczeń sadowych w tradycji prawa anglosaskiego, Torun 2017, s. 39.

5 Zob. T. Stawecki, Precedens jako zadanie dla nauk prawnych, [w:] Precedens $w$ polskim systemie prawa, red. A. Śledzińska-Simon, M. Wyrzykowski, Warszawa 2010, s. 250.

${ }^{6}$ Dz.U. z 1997 r. Nr 78, poz. 483 z późn. zm. 
sąd lub organ administracji publicznej orzeka ostatecznie o jego wolnościach lub prawach albo o jego obowiązkach określonych w Konstytucji.

L. Kieres zgłosił zdanie odrębne do wyroku Trybunału Konstytucyjnego dotyczącego zgodności z Konstytucją przepisu określającego opłatę sądową od skargi na orzeczenie Krajowej Izby Odwoławczej (KIO) przy Prezesie Urzędu Zamówień Publicznych (UZP) ${ }^{7}$. Skarżący, w dwóch skargach konstytucyjnych, które ze względu na tożsamość przedmiotową kontroli zostały rozpoznane łącznie, wnosili o kontrolę konstytucyjności art. 34 ust. 2 ustawy z 28 lipca 2005 roku o kosztach sądowych w sprawach cywilnych (u.k.s.s.c.) ${ }^{8}$. Przepis ten stanowił, że jeżeli skarga na orzeczenie KIO przy Prezesie UZP dotyczy czynności w postępowaniu o udzielenie zamówienia publicznego podjętych po otwarciu ofert, pobiera się opłatę stosunkową w wysokości 5\% wartości przedmiotu zamówienia w postępowaniu, którego skarga dotyczy, jednak nie więcej niż $5 \mathrm{mln}$ zł. Wprowadzenie opłaty stosunkowej z górną granicą wydaje się standardową techniką legislacyjną w stanowieniu przepisów dotyczących kosztów sądowych. Trybunał Konstytucyjny uznał zaskarżony przepis za zgodny z Konstytucją w zakresie, w jakim określał on opłatę stosunkową od skargi na orzeczenie KIO przy Prezesie UZP, a w pozostałym zakresie postępowanie umorzył. Trybunał dekodował bowiem z art. 34 ust. 2 u.k.s.s.c. dwie normy prawne: jedną dotyczącą opłaty stosunkowej i drugą dotyczącą jej górnej granicy ${ }^{9}$. Uznał, że druga z norm nie miała zastosowania do żadnej z dwóch skarżących, w przypadku których opłaty sądowe były niższe niż $5 \mathrm{mln}$ zł (a więc na podstawie tej normy nie orzeczono ostatecznie o ich prawach ani obowiązkach). Ich konstytucyjne prawa nie mogły zostać naruszone normą określającą taką maksymalną opłatę sądową, więc w tym zakresie postępowanie zostało umorzone. Z kolei gdy chodzi o określenie opłaty stosunkowej, Trybunał nie uznał, by naruszało ono konstytucyjne prawo do sądu.

Spośród całego składu orzekającego jedynie L. Kieres (oraz A. Wróbel, który przyłączył się do jego zdania odrębnego) dostrzegł, iż błędem było wyprowadzenie przez Trybunał Konstytucyjny dwóch samodzielnych norm prawnych z art. 34 ust. 2 u.k.s.s.c. Jak podkreślił: ,teza ta doprowadziła Trybunał do wniosku, że obowiązywanie tych dwóch odrębnych norm [...] wywołało skutki również w procesach stosowania prawa poprzedzających kontrolę ich konstytucyjności [...], wpływając pośrednio na zdolność skargową podmiotów chcących zainicjować postępowanie przed TK" ${ }^{10}$. Jego zdaniem przepisu art. 34 ust. 2 u.k.s.s.c. nie można dzielić na dwie autonomiczne części (część poświęconą opłacie stosunkowej i jej

7 Wyrok TK z dnia 14 stycznia 2014 r., SK 25/11, Dz.U. z 2014 r. poz. 106.

8 Tekst jedn. Dz.U. z 2016 r. poz. 623 z późn. zm. Co interesujące, przepis, o którym mowa, utracił moc z dniem 28 kwietnia 2014 r. na podstawie wyroku Trybunału Konstytucyjnego z dnia 15 kwietnia 2014 r., SK 12/13, Dz.U. z 2014 r. poz. 545. Omawiany tu wyrok, jak się wydaje, nie pozostał bez wpływu na późniejszy wyrok derogujący kontrolowany przepis.

9 Pkt 2.3 uzasadnienia wyroku.

10 Pkt 2 in fine zdania odrębnego. 
procentowej wysokości oraz część dotyczącą górnej kwotowej granicy opłaty), a następnie każdą z nich interpretować i analizować osobno, w oderwaniu od ich normatywnego związku. Każdy z tych dwóch elementów pełni określoną funkcję i dopiero jednoczesne zastosowanie obu powiązanych funkcjonalnie komponentów realizuje ratio legis unormowania. Tak też sądy powszechne zdawały się stosować to unormowanie, czemu w żaden sposób nie przeczyły — w konkretnych przypadkach - opłaty sądowe w wysokości poniżej wartości maksymalnej ani brak konieczności jej redukcji do $5 \mathrm{mln}$ zł. Dokonując zabiegu powodującego, że w sprawach, w których opłata wyniosłaby poniżej górnej jej granicy, skarga konstytucyjna przysługiwałaby tylko na pewien zakres art. 34 ust. 2 u.k.s.s.c., w sprawach zaś, w których opłata byłaby maksymalna, skarga konstytucyjna przysługiwałaby bez zakresowych ograniczeń, Trybunał Konstytucyjny zastosował - jak to określił L. Kieres - swego rodzaju unik pozwalający mu nie zająć stanowiska w kwestii kosztów sądowych w procedurach zamówień publicznych.

Zdolność skargowa nie może być uzależniona od wysokości opłaty sądowej ustalonej w procesie stosowania prawa. Rzeczywistą przesłanką skargi konstytucyjnej nie może być wysokość opłaty sądowej od skargi wnoszonej na orzeczenie KIO. Cały przepis, który przewiduje opłatę oraz górną jej granicę, powinien podlegać kontroli konstytucyjności, a zakresowość powinna pozostać cechą procesu wyznaczania przedmiotu niezgodności przepisu z Konstytucją, do którego - jak zauważył L. Kieres - w omawianej sprawie Trybunał Konstytucyjny w ogóle nie przeszedł. Sztuczne rozdzielanie takich „złożonych” konstrukcji prawnych i odnoszenie ich elementów do procesu stosowania prawa odbywa się ze szkodą dla kontroli jego konstytucyjności. Można przyjąć, że podążając za tokiem rozumowania ukazanym w uzasadnieniu omawianego wyroku, hipotetycznie Trybunał mógłby w ten sam sposób rozdzielać konstrukcje sankcji prawnych posługujące się górną granicą sankcji (por. niektóre administracyjne kary pieniężne). Przy takim wadliwym podejściu Trybunału skarga konstytucyjna dotycząca nie samego charakteru sankcji prawnej, lecz jej nieproporcjonalnej wysokości (w ocenie skarżącego generalnie nadmiernej ze względu na jej górną granicę) byłaby dla podmiotu, wobec którego dany rodzaj sankcji ma zastosowanie, nieosiągalna, dopóki nie zostałaby na ten podmiot nałożona sankcja maksymalna. To prowadziłoby do wniosków ad absurdum, ale też do nieuzasadnionego i szkodliwego zawężenia kognicji Trybunału Konstytucyjnego.

\section{WADLIWE STOSOWANIE PRAWA I NIEZNAJOMOŚĆ PRAWA A OCENA KONSTYTUCYJNOŚCI}

Innego rodzaju problemy leżały u podstaw rozstrzygnięcia w sprawie z pytania prawnego Wojewódzkiego Sądu Administracyjnego w Krakowie dotyczącego zgodności z Konstytucją przepisu określającego termin złożenia właściwe- 
mu naczelnikowi urzędu skarbowego zgłoszenia nabycia w drodze dziedziczenia własności rzeczy lub praw majątkowych przez małżonka, zstępnych, wstępnych, pasierba, rodzeństwo, ojczyma i macochę (,zerowa” grupa podatkowa), mającego na celu zwolnienie nabycia z podatku od spadków i darowizn.

Trybunał Konstytucyjny uznał art. 4a ust. 1 pkt 1 ustawy z 28 lipca 1983 roku o podatku od spadków i darowizn (u.p.s.d.) ${ }^{11}$, w brzmieniu obowiązującym od 1 stycznia 2007 roku do 31 grudnia 2008 roku, w zakresie, w jakim przewidywał na powyższe zgłoszenie termin miesięczny liczony od dnia uprawomocnienia się orzeczenia sądu stwierdzającego nabycie spadku, za niezgodny z wywiedzioną $\mathrm{z}$ art. 2 Konstytucji zasadą ochrony zaufania do państwa i stanowionego przez nie prawa ${ }^{12}$. Trybunał podkreślił, że zasada ta wyraża się między innymi w takim stanowieniu i stosowaniu prawa, by nie stawało się ono swoistą pułapką na jednostkę i aby mogła ona układać swoje sprawy w zaufaniu, iż nie naraża się na prawne skutki, których nie mogła przewidzieć w momencie podejmowania decyzji1 ${ }^{13}$. Zdaniem Trybunału, kontrolowany przepis był z tą zasadą niezgodny. Trybunał stwierdził, że sądy powszechne stosują dwa rodzaje pieczęci dotyczącej prawomocności orzeczenia. W rezultacie nabywcy mogli otrzymywać odpis orzeczenia $\mathrm{z}$ datą pieczęcią zawierającą informację o uprawomocnieniu się orzeczenia sądu z upływem określonego dnia lub o dacie przystawienia pieczęci. Mogło to prowadzić do konfuzji i błędnego przyjęcia początkowej daty miesięcznego terminu na złożenie zgłoszenia organowi podatkowemu. Zdaniem Trybunału krótki termin na złożenie zgłoszenia organowi podatkowemu nie pozwalał na pozyskanie informacji o treści obowiązujących przepisów i praktyce ich stosowania oraz skorygowanie przez nabywców ich postępowania.

Trybunał Konstytucyjny zauważył też, że przyjmowane przez organy administracji publicznej oraz sądy administracyjne powszechne założenia aksjologiczne, reguły wykładni prawa i porządek ich stosowania nie pozostają bez wpływu na treść rekonstruowanych norm prawnych oraz że w sprawie takiej jak omawiana ocena zakwestionowanej regulacji pod względem zgodności z zasadą zaufania do państwa i stanowionego przez nie prawa nie może abstrahować od utrwalonego w procesie stosowania prawa odczytania art. $4 \mathrm{a}$ ust. 1 pkt 1 u.p.s.d. Praktyka ta zaś była w ocenie Trybunału taka, że choć brakowało po temu podstaw w przepisach prawa, organy podatkowe żądały niekiedy przedłożenia wraz ze zgłoszeniem nabycia odpisu prawomocnego orzeczenia. Czasami taki odpis był dostarczany nabywcy przez sąd po upływie miesięcznego terminu na złożenie zgłoszenia. Jak jednak słusznie skonstatował L. Kieres w zdaniu odrębnym do omawianego wyroku $^{14}$ :

11 Tekst jedn. Dz.U. z 2017 r. poz. 833 z późn. zm.

12 Wyrok TK z dnia 4 czerwca 2013 r., P 43/11, Dz.U. z 2013 r. poz. 692.

13 Pkt 5.1 uzasadnienia wyroku.

14 Pkt 4 zdania odrębnego. 
w takiej sytuacji Trybunał powinien wykazać, że taka wykładnia zaskarżonej normy została utrwalona w procesie jej stosowania przez organy podatkowe i sądy administracyjne. Wymagałoby to udowodnienia, że istnieje utrwalona linia orzecznicza, zgodnie z którą jednym z warunków koniecznych uzyskania zwolnienia jest złożenie odpisu prawomocnego postanowienia sądu o stwierdzeniu nabycia spadku. Gdyby istniała taka linia orzecznicza, organy podatkowe zobowiązane byłyby wydawać decyzje ustalające wysokość zobowiązania podatkowego, mimo złożenia zgłoszenia w terminie miesiąca od dnia uprawomocnienia się tego postanowienia, z powodu braku przedłożenia odpisu postanowienia. Tylko taka praktyka organów podatkowych i wyroki sądów administracyjnych, utrzymujące te decyzje w mocy, wskazywałyby na utrwalone rozumienie zaskarżonej normy w praktyce stosowania prawa. $Z$ analizy orzecznictwa nie wynika, żeby takie rozumienie zaskarżonej normy zostało utrwalone w praktyce jej stosowania. Skoro jednak sam Trybunał wskazuje, że takie sytuacje miały „niekiedy” miejsce, i to w dodatku nie jako warunek zwolnienia, lecz jako udokumentowanie daty powstania obowiązku podatkowego, nieuzasadnione jest nadawanie zaskarżonej normie innego rozumienia, niż wynika ono z wykładni literalnej. Jest to zatem tylko kwestia oceny wadliwego stosowania prawa, która należy do sądów, [...] nie jest natomiast objęta kognicją Trybunału. Trybunał błędnie utożsamił pojedyncze przypadki żądania przedłożenia odpisu postanowienia z utrwaloną praktyką stosowania zaskarżonego przepisu [...].

Uwzględnianie przy abstrakcyjnej ocenie zgodności przepisu z Konstytucją sytuacji, w których organy wzywały niekiedy do przedłożenia odpisu orzeczenia, jako praktyki stosowania prawa pozbawione jest więc podstaw.

Argumenty przemawiające zdaniem Trybunału za niezgodnością zaskarżonego przepisu z Konstytucją pomijały treść zaskarżonego przepisu. Opierały się na pojedynczych przypadkach wadliwej praktyki stosowania prawa, a także nieznajomości prawa przez podmioty uprawnione do skorzystania ze zwolnienia od podatku. Okoliczności te zaś nie powinny wpływać na abstrakcyjną ocenę konstytucyjności przepisu. Należą one, jak zauważa L. Kieres, do orzeczniczej działalności sądów administracyjnych.

\section{STOSOWANIE NIEKONSTYTUCYJNEGO AKTU A KONIECZNOŚĆ KONTROLI}

Sprawa dotycząca zwolnienia nabycia z podatku od spadków i darowizn, o której była mowa, pokazuje, jak w istocie trudne jest ustalenie, czy źródłem naruszenia praw jednostek jest treść przepisu prawa czy też wady interpretacji bądź stosowania tego przepisu oraz czy można mówić o utrwalonej (wadliwej) praktyce jego stosowania, czy też nie. Cenne rozważania w tym przedmiocie przynosi sprawa, w której Rzecznik Praw Obywatelskich (RPO) wniósł o stwierdzenie niezgodności z Konstytucją przepisów ustawy z 17 maja 1989 roku o stosunku Państwa do Kościoła Katolickiego w Rzeczypospolitej Polskiej (u.s.p.k.k.) ${ }^{15}$ oraz ustawy z 20 lutego 1997 roku o stosunku Państwa do gmin wyznaniowych żydowskich

15 Tekst jedn. Dz.U. z 2013 r. poz. 1169 z późn. zm. 
w Rzeczypospolitej Polskiej (u.s.p.g.w.ż.) ${ }^{16}$. Trybunał Konstytucyjny uznał art. 33 ust. 5 w zw. z art. 33 ust. 2 zd. 3 u.s.p.g.w.ż. rozumiany w ten sposób, że nie wyłącza innych niż odwołanie środków prawnych od orzeczenia Komisji Regulacyjnej, za zgodny z Konstytucją, a w pozostałym zakresie umorzył postępowanie ${ }^{17}$.

RPO zarzucił zaskarżonym przepisom brak możliwości zaskarżenia orzeczenia wydanego przez tak zwane komisje regulacyjne. Jego zdaniem oznacza to całkowite pozbawienie jednostek samorządu terytorialnego ochrony sądowej prawa własności odebranego orzeczeniem właściwej komisji. Trybunał Konstytucyjny zinterpretował art. 33 ust. 5 u.s.p.g.w.ż. stanowiący, że od orzeczenia zespołu orzekającego nie przysługuje odwołanie, w ten sposób, że nie wyklucza on ani stosowania pozostałych środków zaskarżenia w toku procedury administracyjnej (wniosku o wznowienie postępowania, wniosku o stwierdzenie nieważności orzeczenia komisji, wniosku o uchylenie lub zmianę ostatecznego orzeczenia komisji), ani sądowej kontroli zgodności z prawem wydanego orzeczenia komisji ${ }^{18}$. Co do przepisów u.s.p.k.k. postępowanie przed Trybunałem zostało umorzone, gdyż zaskarżone przepisy zostały uchylone, a Komisja Majątkowa zakończyła działalność 28 lutego 2011 roku. W sprawie nie doszło do naruszenia konstytucyjnych wolności i praw człowieka i obywatela.

L. Kieres zgłosił zdanie odrębne do omawianego wyroku. Jego zdaniem nie było podstaw do umorzenia postępowania, a Trybunał Konstytucyjny powinien był rozpoznać sprawę merytorycznie. W swym zdaniu odrębnym zawarł wiele istotnych uwag dotyczących jednostki samorządu terytorialnego jako podmiotu konstytucyjnych praw i wolności. Ponadto L. Kieres przyłączył się do argumentacji przedstawionej w omawianej sprawie w zdaniu odrębnym sędziego TK S. Biernata. Objęto nią, po pierwsze, argument, że mimo formalnego uchylenia przepisów ustawy mogą one stanowić przedmiot kontroli zgodności z Konstytucją, gdy w czasie orzekania przez Trybunał toczą się sprawy przed organami państwowymi (organami administracyjnymi lub sądami) i na podstawie formalnie derogowanych przepisów mogą być nadal podejmowane akty stosowania prawa (decyzje administracyjne, orzeczenia sądowe). Takiej też opinii był Trybunał w omawianym wyroku dotyczącym zwolnienia nabycia z podatku od spadków i darowizn ${ }^{19}$. Okoliczność, że Komisja Majątkowa zakończyła swoją działalność, nie miała znaczenia, gdyż w dalszym ciągu przedmiotem kontroli sądowoadministracyjnej były rozstrzygnięcia Komisji z czasu, kiedy jeszcze prowadziła swoją działalność.

16 Tekst jedn. Dz.U. z 2014 r. poz. 1798.

17 Wyrok z dnia 13 marca 2013 r., K 25/10, Dz.U. z 2013 r. poz. 432.

18 Pkt 3.4.11-3.4.12 uzasadnienia wyroku.

19 Zob. pkt 2.3 jego uzasadnienia. Zob. też zdanie odrębne sędziego TK Leona Kieresa (Nb. 262-263) do wyroku z dnia 24 października 2017 r., K 1/17, Dz.U. z 2017 r. poz. 2001, o którym będzie jeszcze mowa dalej. Zob. także P. Radziewicz, Kontrola konstytucyjności „prawa nieobowiązującego", PiP 2014, nr 5, s. 99 n. 
Po drugie, sędziowie argumentowali, że jak wynika z obserwacji stosowania zaskarżonej ustawy, wbrew stwierdzeniom Trybunału Konstytucyjnego, osoby trzecie nie były w stanie skutecznie korzystać z drogi prawnej ochrony swoich praw, a w szczególności były pozbawione prawa do sądu, co wynikało zjudykatury sądów powszechnych, Sądu Najwyższego i sądów administracyjnych. Zasłużonej krytyce poddano fragment uzasadnienia omawianego wyroku - Trybunał powołał się w nim na art. 61 ust. 4 pkt 3 u.s.p.k.k., stosownie do którego regulacja nie może naruszać między innymi praw nabytych przez niepaństwowe osoby trzecie. Na tej podstawie Trybunał wywodził, że prawa osób trzecich nie mogły zostać naruszone. Z przepisu tego można wyprowadzić normę zakazującą takiego interpretowania i stosowania przepisów o postępowaniu regulacyjnym, by w ich wyniku nastąpiło naruszenie praw osób trzecich. Nie można jednak wykluczyć naruszenia takiej normy w praktyce. ,,Jest to fundamentalna dla prawników kwestia rozróżnienia sfer powinności i bytu. Na analogicznej zasadzie można by argumentować, że art. 7 Konstytucji, stosownie do którego organy władzy publicznej działają na podstawie i w granicach prawa, czyni zbędnym funkcjonowanie Trybunału Konstytucyjnego! [...]"20.

Słusznie też wskazano, że dla konieczności kontroli konstytucyjności przepisu nie ma znaczenia skala zjawiska i liczba podmiotów, których prawa zostały naruszone w następstwie stosowania niekonstytucyjnego aktu normatywnego. Trafne i zasadne było nawiązanie do wcześniejszego wyroku Trybunału Konstytucyjnego, w którym w pełnym składzie stwierdzono, że konieczność wydania orzeczenia odnośnie do ochrony konstytucyjnych wolności i praw jednostki zachodzi, wówczas gdy hipotetycznie choćby jeden podmiot konstytucyjnych wolności i praw może skorzystać na wyeliminowaniu przez Trybunał badanego przepisu z systemu prawnego $^{21}$.

\section{PRZYSZŁA PRAKTYKA STOSOWANIA PRAWA A JEGO KONSTYTUCYJNOŚĆ}

Przytoczone przykłady ukazują, że Trybunał Konstytucyjny staje przed niejednokrotnie bardzo trudnym zadaniem oceny, czy to przepisy prawa są niezgodne z Konstytucją, czy też to podmioty stosujące przepisy prawa zgodne z Konstytucją nie potrafią ich prawidłowo zinterpretować i zastosować. Nieco inaczej prezentuje się owo zadanie Trybunału, gdy nie ma jeszcze praktyki stosowania kontrolowanego przepisu prawa. Dotyczy to w szczególności postępowania inicjowanego wnioskiem złożonym w trybie kontroli prewencyjnej.

20 Pkt 3 zdania odrębnego.

21 Zob. uzasadnienie wyroku z dnia 16 marca 2011 r., K 35/08, OTK ZU nr 2/A/2011, poz. 11. 
Przykładem takiego postępowania z wniosku prewencyjnego, w którym L. Kieres zgłosił zdanie odrębne do wyroku Trybunału, było postępowanie z wniosku Prezydenta RP o zbadanie zgodności z Konstytucją szeregu przepisów ustawy z 13 grudnia 2016 roku o zmianie ustawy — Prawo o zgromadzeniach ${ }^{22}$. Trybunał uznał część zaskarżonych przepisów za zgodne z Konstytucją, a co do części postępowanie umorzył. Profesor Kieres zgłosił zdanie odrębne do wyroku w zakresie, w jakim umorzono postępowanie co do przepisu, w którym pominięto kwestię dopuszczalności zaskarżenia przez organizatora zgromadzenia zarządzenia zastępczego wojewody o zakazie zgromadzenia. Trybunał zajął stanowisko, że nie było to pominięcie ustawodawcze (lecz zaniechanie ustawodawcze) i zaproponował zastosowanie $\mathrm{w}$ dyskusyjnej kwestii innych przepisów, w tym art. 16 ust. 1 ustawy - Prawo o zgromadzeniach dotyczącego decyzji gminy o zakazie zgromadzenia i jej zaskarżenia ${ }^{23}$. Profesor Kieres wskazał w zdaniu odrębnym, że tezy o zaniechaniu (a nie pominięciu) ustawodawczym nie można uzasadniać możliwością dokonania wykładni prokonstytucyjnej innego niezaskarżonego przepisu oraz że wykładnia prokonstytucyjna nie może opierać się na dodaniu do przepisu, który nie został zaskarżony, nowej treści normatywnej. Wreszcie, dobitnie podkreślił, że w postępowaniu inicjowanym wnioskiem prewencyjnym trudno przewidzieć, jak ukształtuje się praktyka stosowania prawa na gruncie zaskarżonego przepisu.

Wątek związany z przyszłą praktyką stosowania kontrolowanego przepisu wybrzmiewa jeszcze mocniej w zdaniu odrębnym L. Kieresa do wyroku ${ }^{24}$ dotyczącego zgodności z Konstytucją przepisów ustaw dotyczących Trybunału Konstytucyjnego. Zgłaszając zdanie odrębne, poruszył wiele istotnych wątków, jak wygaszanie stosunku pracy pracowników Biura TK, zaniechanie ogłoszenia w Dzienniku Ustaw wyroków TK, skład Trybunału Konstytucyjnego czy możliwość orzekania o uchylonych przepisach tylko na skutek skargi konstytucyjnej. Zdaniem odrębnym zostało objęte również zagadnienie składania przez Prezydenta RP zawiadomienia o podejrzeniu popełnienia przez sędziego TK deliktu dyscyplinarnego, czyli nowej instytucji uregulowanej w art. 26 pkt 2 ustawy z 30 listopada 2016 r. o statusie sędziów Trybunału Konstytucyjnego ${ }^{25}$, który został uznany przez Trybunał za zgodny z Konstytucją. Profesor Kieres ocenił to stanowisko jako trafne, ale tylko pod warunkiem że przepis ten będzie stosowany $\mathrm{z}$ umiarem i rozwagą, a nie nadużywany w doraźnych celach politycznych i wywieraniu na sędziów TK niezgodnej z prawem presji.

22 Dz.U. z 2017 r. poz. 579.

23 Zob. też M. Florczak-Wątor, Zgromadzenia cykliczne-glosa do wyroku TK z dnia 16 marca 2017 r., Kp 1/17, LEX/el.

24 Wyrok z dnia 24 października 2017 r., K 1/17, Dz.U. z 2017 r. poz. 2001, http://ipo.trybunal. gov.pl/ipo/Sprawa?\&pokaz=dokumenty\&sygnatura $=\mathrm{K} \% 201 / 17$.

25 Tekst jedn. Dz.U. z 2016 r. poz. 2073 z późn. zm. 
Należy przyjąć założenie, że organy władzy publicznej, włączone w proces inicjowania postępowania dyscyplinarnego sędziów TK, są świadome możliwych destrukcyjnych skutków pochopnego skorzystania z tego uprawnienia dla autorytetu sędziów i Trybunału — nie można a priori przypisywać im złej woli. Przeciwnie — należy uznać, że Prokurator Generalny, Pierwszy Prezes Sądu Najwyższego, a nade wszystko Prezydent, rozważając zasadność skierowania wniosku w sprawie podejrzenia popełnienia deliktu dyscyplinarnego przez sędziego TK, będą kierować się szczególnym poczuciem odpowiedzialności $[\ldots]^{26}$.

Gdyby jednak praktyka stosowania kwestionowanej regulacji okazała się inna, to - jak słusznie zauważa Profesor — należałoby zweryfikować ocenę jej konstytucyjności.

Zdania odrębne Leona Kieresa do wyroków Trybunału Konstytucyjnego są merytorycznie uzasadnione i wyważone. Często motywuje je troską o efektywność środków wnoszonych do Trybunału Konstytucyjnego jako organu stojącego na straży konstytucyjności prawa oraz praw podstawowych jednostki. Zwraca uwagę na doniosłość badanych zagadnień dla szeroko pojętej gospodarki narodowej czy pozycji ustrojowej polskiego samorządu terytorialnego oraz konstytucyjnych gwarancji samodzielności i podmiotowości prawnej jednostek samorządu terytorialnego. Stąd też w zgłaszanych zdaniach odrębnych często poświęca uwagę kwestiom stosowania prawa. Tacy właśnie sędziowie Trybunału Konstytucyjnego są potrzebni. Oby tak dalej.

\section{THE APPLICATION OF LAW AND THE CONTROL OF ITS CONSTITUTIONALITY (DISSENTING OPINIONS FILED BY PROFESSOR LEON KIERES REGARDING THE JUDGMENTS OF THE CONSTITUTIONAL TRIBUNAL)}

\section{Summary}

This article provides readers with information relating to dissenting opinions filed by Prof. Leon Kieres regarding the judgments of the Constitutional Tribunal. The intention of the author is to present Professor's views on the application of law in various contexts. Therefore, separate subsections present a review of his ideas on the following topics: the application of law and the ability to complain to the Constitutional Tribunal, the incorrect application of law/ignorance of law and the assessment of constitutionality, the application of the unconstitutional law and the need for control, the future practice of applying the law and its constitutionality.

Keywords: the application of law, the control of constitutionality, judgments of the Constitutional Tribunal, dissenting opinions

$26 \mathrm{Nb} .245$ zdania odrębnego. 


\section{BIBLIOGRAFIA}

Florczak-Wątor M., Zgromadzenia cykliczne - glosa do wyroku TK z dnia 16 marca 2017 r., Kp 1/17, LEX/el.

Piotrowski R., Konstytucja i uniwersytety, [w:] Prawo, parlament i egzekutywa we wspótczesnych systemach rządów. Księga poświęcona pamięci Profesora Jerzego Stembrowicza, red. S. Bożyk, Białystok 2009.

Radziewicz P., Kontrola konstytucyjności „prawa nieobowiąującego”, „Państwo i Prawo” 2014, nr 5.

Stawecki T., Precedens jako zadanie dla nauk prawnych, [w:] Precedens w polskim systemie prawa, red. A. Śledzińska-Simon, M. Wyrzykowski, Warszawa 2010.

Zdziennicki B., Zdania odrębne w orzecznictwie polskiego Trybunału Konstytucyjnego, [w:] Księga XX-lecia orzecznictwa Trybunału Konstytucyjnego, red. M. Zubik, Warszawa 2006.

Zych T., W poszukiwaniu pewności prawa. Precedens a przewidywalność orzeczeń sadowych w tradycji prawa anglosaskiego, Toruń 2017. 